\title{
PROFITABILITY AND TECHNICAL EFFICIENCY IN HOMESTEAD CATFISH PRODUCTION IN DELTA STATE, NIGERIA
}

\section{Odjuvwuederhie Emmanuel Inoni', 'Oraye Dicta Ogisi', Felix Odemero Achoja ${ }^{3}$}

\begin{abstract}
Summary
The study examined the profitability and technical efficiency in homestead catfish production in the central agricultural zone of Delta State, Nigeria. Primary data were obtained from 162 homestead catfish farmers with the aid of well-structured questionnaire, using multi-stage sampling procedure. Budgetary analysis and stochastic frontier production function were used to analyse the data. Catfish production was found to be profitable with a net margin of 67.17/ kg; net margin of $490.31 / \mathrm{m}^{2}$ and a net margin-total cost ratio of 29\%. Maximum likelihood estimates (MLE) results indicated that pond size, feeds, fingerlings and labour positively and significantly affected homestead catfish output. The returns to scale (RTS) of 2.26 implied that the farm firms in the area exhibited increasing returns to scale. Technical efficiency of catfish farms ranged from $28 \%$ to $96 \%$ with an average of $87 \%$. Observed inefficiency was due to age, education, credit access and household size.
\end{abstract}

Key words: Profitability, Stochastic Frontier Function, Technical Efficiency, Homestead Catfish Production.

JEL: Q10, Q12, Q13

\section{Introduction}

The global fish supply from both capture fisheries and aquaculture was put at 167.2 million tonnes in 2014, with 146.3 million tonnes used for human consumption and providing an estimated apparent food fish per capita supply of about $20.1 \mathrm{~kg}$ (live weight equivalent). The contribution of aquaculture to world fish supply reached an alltime level of 73.8 million tonnes in 2014 representing $44.14 \%$ of global fish production;

1 Inoni, Odjuvwuederhie Emmanuel, Ph.D., Professor, Department of Agricultural Economics \& Extension, Faculty of Agriculture, Delta State University, Abraka. Delta State, Nigeria, Phone: +234 803374 6331, Email: eoinoni@delsu.edu.ng; inoniemma@gmail.com

2 Ogisi, 'Oraye Dicta, Ph.D., Professor, Department of Agricultural Economics \& Extension, Faculty of Agriculture, Delta State University, Abraka. Delta State, Nigeria. Email: odogisi@delsu.edu.ng

3 Achoja, Felix Odemero, Ph.D., Senior Lecturer, Department of Agricultural Economics \& Extension, Faculty of Agriculture, Delta State University, Abraka. Delta State, Nigeria. Email: foachoja@delsu.edu.ng

EP 2017 (64) 4 (1449-1465) 
while the values were 1.711 million tonnes and 556.9 tonnes respectively for Africa and sub-Saharan Africa (FAO, 2016). Aquaculture has continued to remain a growing, vibrant and important production sector for high protein food fish supply for human consumption in developing countries. Besides, it is a veritable source of income and employment for over 284,000 fish farmers in Africa, and many more people engaged in fish processing and marketing (FAO, 2016).

Although domestic fish production has been growing in Nigeria since the year 2005, fish supply has continually fallen short of demand due to the rapidly growing human population. The situation has led to a widening demand-supply gap which has led to huge importation of fish to augment local demand. Nigeria's fish import grew from 246,850 tonnes in 2000 to 2,027,797 tonnes in 2011, culminating in an annual average fish import of 738,308.69 metric tonnes between 2000 and 2012 (Figure 1). The nation's fish import bill gulped a whooping US 2.03 billion dollars in 2011, making Nigeria one of the largest importers of fish in the developing world (FAO, 2014). Furthermore, the value of Nigeria's import of fishery products stood at 1.31 billion US dollars in 2014 , accounting for $23.4 \%$ of the value of fishery commodities import in Africa (FAO, 2016a).

Figure 1. Fish production, Fish Import and Net Fish Export in Nigeria

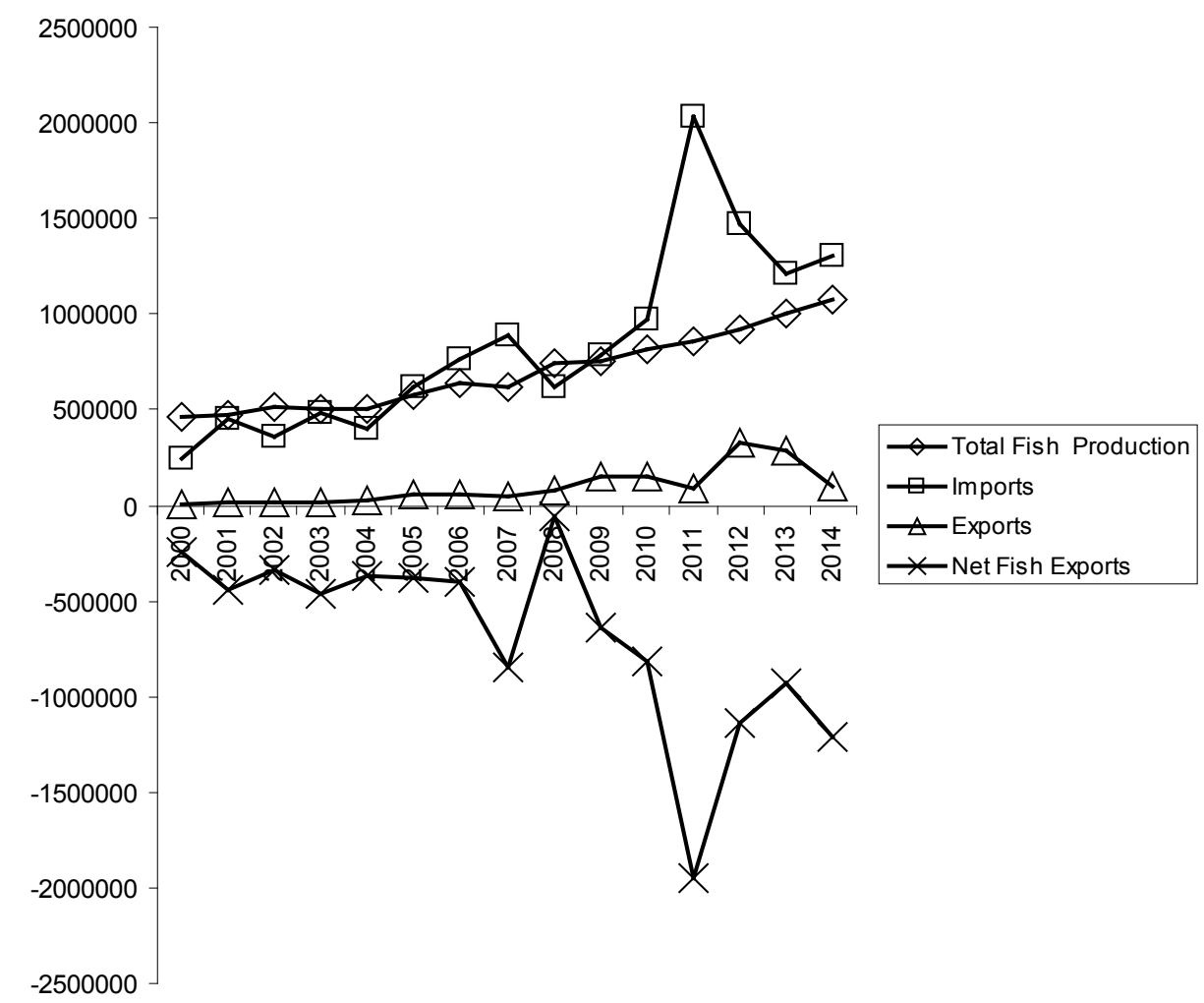

Source: FAO, Yearbook of Fisheries and Aquaculture Statistics (2006, 2008, 2012)

FAO, State of World Fisheries and Aquaculture, 2016; FAO, FishstatJ, 2017 
Aquaculture, the farming of aquatic organisms, including fish, molluscs, crustaceans and aquatic plants, is often cited as one of the means of efficiently increasing fish production in low-income, food-deficit countries. Aquaculture production has experienced a steady growth in Nigeria since the year 2000. With an output level of 24,398 metric tonnes in 2001, production reached a level of 313,231 metric tonnes in the year 2014 (Table, 1). Food and Agriculture Organisation estimates revealed that the catfishes Clarias gariepinus, Clarias species and, Clarias-Heterobranchus hybrid appear to be the dominant cultured fish species in Nigeria, as they accounted for $61.4 \%$ of total aquaculture production in the year 2007 (FAO, 2009).

Table 1. Nigeria; Fish Production, Import and Export Bill

\begin{tabular}{|l|l|l|l|l|l|l|c|}
\hline Year & $\begin{array}{l}\text { Total fish } \\
\text { production } \\
\text { (tonnes) }\end{array}$ & $\begin{array}{l}\text { Capture } \\
\text { fisheries } \\
\text { (tonnes) }\end{array}$ & $\begin{array}{l}\text { Aquaculture } \\
\text { (tonnes) }\end{array}$ & $\begin{array}{l}\text { Catfish } \\
\text { (tonnes) }\end{array}$ & $\begin{array}{l}\text { Imports } \\
\text { (US\$ '000) }\end{array}$ & $\begin{array}{c}\text { Exports } \\
\text { (US\$ '000) }\end{array}$ & $\begin{array}{c}\text { Net Fish } \\
\text { Exports } \\
\text { (US\$ '000) }\end{array}$ \\
\hline 2000 & 467,095 & 441,377 & 25,718 & 4,067 & 246,850 & 1,572 & $-245,278$ \\
\hline 2001 & 476,544 & 452,146 & 24,398 & 4,387 & 452,770 & 13,786 & $-438,984$ \\
\hline 2002 & 511,719 & 481,056 & 30,663 & 7,134 & 359,997 & 16,979 & $-343,018$ \\
\hline 2003 & 505,839 & 475,162 & 30,677 & 10,015 & 484,423 & 17,733 & $-466,690$ \\
\hline 2004 & 509,201 & 465,251 & 43,950 & 26,750 & 396,535 & 29,891 & $-366,644$ \\
\hline 2005 & 579,537 & 523,182 & 56,355 & 34,582 & 613,497 & 56,827 & $-375,676$ \\
\hline 2006 & 636,901 & 552,323 & 84,578 & 51,916 & 766,089 & 53,755 & $-400,493$ \\
\hline 2007 & 615,507 & 530,420 & 85,087 & 52,229 & 892,771 & 50,126 & $-842,645$ \\
\hline 2008 & 744,575 & 601,368 & 143,207 & 36,330 & 618,062 & 75,106 & $-542,956$ \\
\hline 2009 & 751,006 & 598,210 & 152,796 & 75,662 & 786,075 & 146,931 & $-639,144$ \\
\hline 2010 & 817,516 & 616,981 & 200,535 & 115,421 & 973,724 & 154,608 & $-819,116$ \\
\hline 2011 & 856,614 & 635,486 & 221,128 & 122,681 & $2,027,797$ & 83,824 & $-194,3973$ \\
\hline 2012 & 922,652 & 668,754 & 253,898 & 125,762 & $1,472,258$ & 331,052 & $-114,1206$ \\
\hline 2013 & $1,000,061$ & 721,355 & 278,706 & 144,927 & $1,213,562$ & 283,390 & $-930,170$ \\
\hline 2014 & $1,073,059$ & 759,828 & 313,231 & 157,748 & $1,308,947$ & 93,573 & $-1,215,374$ \\
\hline
\end{tabular}

Source: FAO, Yearbook of Fisheries and Aquaculture Statistics (2006, 2008, 2012)

FAO, State of World Fisheries and Aquaculture, 2014; FAO, FishstatJ, 2017.

The preference of farmers to culture catfish may be due to their better growth performance and survivability (Adeogun, et. al. 2008), as well as a better market value that is two to three times that of tilapia (Olagunju, et. al. 2007). The level of aquaculture production appears to be rather low, giving the declining yield of natural fish stocks due to over-exploitation and climate change, coupled with the annual huge loss in foreign exchange to fish importation. Given the present scenario, fish farming, especially catfish farming still holds the greatest potentials to rapidly boost domestic fish production and place the nation on the part towards self-sufficiency in fish production (Ugwumba, 2005; Inoni, 2007). 


\section{Statement of Problem}

Fish farming is a major component of the agricultural production system in Delta State because of the abundant land and water resources that can support the cultivation of both marine and freshwater fish species. The prevailing hydrographic conditions have thus made fish farming a thriving agribusiness investment for small-scale fish farmers in the State.

Although a number of studies may have been carried out on the economics and profitability of fish farming in many States in Nigeria including Delta State, not many such studies have focused on the profitability and technical efficiency in catfish production at the homestead level in the central agricultural zone of Delta State. This is the gap that this study is conceived to fill. The specific objectives of this study therefore are to describe the socio-economic characteristics of catfish farmers; assessed the profitability as well as determine technical efficiency in homestead catfish production.

\section{Empirical Literature on Profitability and Efficiency of Catfish Production}

Ogundari and Ojo (2009) in a study of income generation potential and resource-use efficiency of 120 aquaculture farms in Oyo state Nigeria, reported that fish farms were quite profitable based on the average gross margin of $207,000.00$ per annum. According to them resources were efficiently utilised with a mean technical efficiency of $81 \%$. The results also revealed that extension contact, level of education, stocking density, and access to credit were the factors that significantly influenced the level of technical efficiency of the fish farms. The authors recommended that policy variables such as extension, education, and credit identified in the study as important determinants of technical efficiency of the farms should strengthen for sustainable fish production in the State.

In another study on 'economic analysis of homestead fish production in Ogun State Nigeria', Olawumi, Dipeolu and Bamiro (2010) examined determinants of revenue and found that pond size, quantity of fish seeds stocked, labour in feeding and harvesting as well as the poultry waste are the major determinants of the revenue that accrued to homestead fish farmers. The study concluded that policy variables such as pond size, labour and fingerlings that influence the revenue from fish farming should be strengthened for sustainable fish production to be attained in the study area.

The report by Ugwumba and Chukwuji (2010) seemed to confirm the profitability of catfish farming Using data obtained from a cross section of 204 catfish farmers in Anambra State, they found net returns on investment of 0.61 while fish feeds constituted over $70 \%$ of the total cost of production. Cost of feeds had a negative and significant effect on profitability while output price exerted a positive significant influence. High cost of feeds, lack of capital, scarcity of fingerlings, lack of modern technologies, high cost of transportation, high cost of labour, lack of land, poaching, inadequate water supply, mortality of fish and lastly poor storage facilities were ranked the most serious constraints to catfish production. The authors recommended that government policies 
should support the establishment of mills that can produce pelleted and floating feeds, modern hatcheries, and provision of credit facilities as well as intensification of fisheries extension services to farmers.

Using translog form of stochastic frontier production function in an empirical analysis of efficiency of resource-use among rural fish farmers in Rivers State, Nigeria, Onoja and Achike (2011) reported that fish farms had a mean technical efficiency of $71 \%$ with farm area and water supply system as significant determinants of technical efficiency. The study concluded that the productivity of factors can be improved by culturing high quality fingerlings, training farmers on current techniques of fish farming as well as optimal utilization of quality feeds.

\section{Materials and Methods}

\section{Sampling Procedure and Data Collection}

The Delta Central Agricultural zone was chosen for the study because it has abundant land and water resources that can support the production of freshwater fish species. In fact, the prevailing hydrographic conditions of the area have made fish farming a thriving agribusiness investment for small-scale fish farmers. The Delta Central agricultural zone of the State comprised ten (10) local government areas (LGAs); Udu, Uvwie, Okpe, Isoko North, Isoko South, Sapele, Ethiope West, Ethiope East, Ughelli North and Ughelli South.

Multi-stage sampling procedure was used to draw samples for the study. Out of the ten (10) local government areas (LGAs) that comprised the Delta Central Agricultural zone, five (5) LGAs of Isoko South, Ughelli North, Uvwie, Ethiope East, and Isoko North were randomly drawn using simple random sampling technique Secondly, two major fish farming communities were randomly selected from each of the 5 LGAs earlier chosen. Thus, a total of 10 communities were covered in the survey. Finally, 20 homestead catfish producers were drawn from each of the 10 communities to give a total sample size of 200 homestead catfish farmers sampled in the study.

Primary data for the study were obtained from a cross-section of homestead catfish farmers using a structured questionnaire. Location of fish farmers were obtained from dealers of fish feeds and feed ingredients in the area as well as catfish farmers earlier identified by the researchers. These were complemented with information obtained from Agricultural Officers in the selected LGAs. However due to non-response and inadequate information, thirty-eight (38) copies of the questionnaire were discarded, and data from only 162 respondents were used for the analysis. Data collected included social characteristics of the catfish farmers such as age, sex, marital status, household size, educational level, and fishing experience; types and quantity of inputs used, pond size, output of fish, input and output prices, fish sales, production period, and labour utilization. The field survey was conducted between $15^{\text {th }}$ October and 20 $0^{\text {th }}$ December, 2015. 


\section{Stochastic Frontier Model Specification}

The stochastic frontier model proposed by Aigner et al. (1977) Coelli (1996) was used to determine technical efficiency in homestead catfish production. The model has been widely used to study farm level efficiency and sources of inefficiency inherent in agricultural production processes (Coelli et al., 2005).

According to Greene (2008), a general stochastic production frontier model can be specified as:

$$
\ln q_{i}=f(\ln X)+v_{i-} u_{i}
$$

where $q_{i}$ is the output $(\mathrm{kg})$ of catfish produced by firm $i, \mathrm{x}$ is a vector of factor inputs, $v_{i}$ is the stochastic (white noise) error term and $u_{j}$ is a one-sided error representing the technical inefficiency of firm $i$. Both $v_{i}$ and $u_{i}$ are assumed to be independently and identically distributed (iid) with variance and respectively.

Therefore, the production of each firm $i$ can be estimated as;

$$
\ln \hat{q}_{i}=f(\ln X)-u_{i}
$$

while the efficient level of production (i.e. no inefficiency) can be defined as;

$$
\ln q^{*}=f(\ln X)
$$

Then according to Chukwuji et.al. (2007) technical efficiency (TE) can be given by:

$$
\ln T E_{i}=\ln \hat{q}_{i}-\ln q^{*}=-u_{i}
$$

Thus,

$$
T E_{i}=e^{-u_{i}}
$$

and is constrained to be between zero and one in value. If $u_{j}$ equals zero, then TE equals one, and production is said to be technically efficient. Technical efficiency of the $i$ th firm is therefore a relative measure of its output as a proportion of the corresponding frontier output. A firm is technically efficient if its output level is on the frontier, which implies that $\mathrm{q} / \mathrm{q}^{*}$ equals one in value.

The Cobb-Douglas form of the stochastic frontier production model is stated explicitly as;

$$
l n q_{i}=\beta_{0}+\beta_{1} p d z+\beta_{2} \operatorname{lnlbr}+\beta_{3} \operatorname{lnfds}+\beta_{4} f g n+v_{i-} u_{i}
$$

Where the variables are as defined earlier.

In order to examine factors that influence catfish farmers' level of inefficiency, an inefficiency model was jointly estimated with the stochastic frontier production function as;

$$
\mu_{i}=\varphi_{0} A G E+\varphi_{1} H H Z+\varphi_{2} E D U+\varphi_{3} F E X+\varphi_{4} C R E D A C+\omega_{I}
$$


Where,

AGE, is catfish farmer's age,

$\mathrm{HHZ}$, is is house hold size, that is number of persons in the household,

EDU, is years of formal education,

FEX, is number of years of fish farming,

CREDAC, is access to credit (a dummy variable where, $1=$ have access; $0=$ no access)

A negative coefficient of () implies decrease in inefficiency while a positive implies an increase in inefficiency. Maximum Likelihood Estimation (MLE) method was used to estimate the parameters of the models with the aid of the computer program, FRONTIER 4.1c (Coelli, 1996). likelihood ratio (LR) statistic was used to test the relevant hypotheses.

\section{Profitability in Catfish Production}

The budgetary analysis which involved the costs and returns analysis was used to determine the profitability or otherwise of homestead catfish production as follows;

$$
\pi=T R-T C ;
$$

Gross Margin $=$ TR - TVC

Net Margin = GM - TFC

But $\mathrm{TR}=\mathrm{PQ}$; and $\mathrm{TC}=\mathrm{TVC}+\mathrm{TFC}$

Where, is profit, TR is Total Revenue; TC is Total Cost; TVC is total Variable Cost; TFC is Total Fixed Cost; $\mathrm{P}$ is unit price of catfish ( $)$; Q is output of catfish (kg).

Apart from the net margin, the net margin-to-total cost ratio was also computed to affirm whether homestead catfish production was indeed profitable in the study area.

\section{Results and Discussion}

\section{Socio-economic Characteristics of Homestead Catfish Farmers}

The socio-economic characteristics of catfish farmers (Table 2) revealed that although both men and women were actively involved in homestead catfish production in the study area, men were more dominant in numbers with $72 \%$ of male farmers. A number of socio-cultural factors limit women access to productive resources, external inputs and information (Doss and Morris (2001). This may have resulted in the fewer number of women participating in homestead catfish production in the study area.

The age of fish farmers ranged between 27 to 68 years with a mean age of 49 years. In fact majority of them $(66.6 \%)$ are within the age range of 41 to 61 years. The effect of age comes from accumulated knowledge and experience (Tenge et al., 2004). Furthermore, older farmers may have more personal capital from long accumulation (Nkamleu and Manyong, 2005) and, thus more likely to invest in new technologies and participate in fish production around the home. 
The household size, the number of persons per household ranged from 1 to 10 with an average size of 5 per household. Household size is related to the role members play as sources of labour in fish farming activities. Homestead catfish farming operations require a great deal of human effort from stocking, routine management to harvesting. Thus households with increased labour supply are more likely to adopt and participate in labour-intensive new technologies than those with fewer persons per household (Nkamleu and Manyong, 2005; Amsalu and de Graaff, 2007).

Operators of all the fish farms studied acquired some level of formal education. The modal educational status amongst the farmers was senior secondary education. Generally education is thought to create a favourable mental attitude for the

Table 2. Distribution of socioeconomic characteristics of homestead catfish farmers (n $=162$ )

\begin{tabular}{|c|c|c|}
\hline Parameter & Frequency & $\begin{array}{l}\text { Mean } \\
\text { (Mode) }\end{array}$ \\
\hline \multicolumn{3}{|l|}{ Sex } \\
\hline Male & $117(72.2)^{*}$ & (Male) \\
\hline Female & $45(27.8)$ & \\
\hline \multicolumn{3}{|l|}{ Age } \\
\hline $27-33$ & $15(9.3)$ & \\
\hline $34-40$ & $22(13.6)$ & \\
\hline $41-47$ & $29(17.9)$ & 49 \\
\hline $48-54$ & $39(24.0)$ & \\
\hline $55-61$ & $40(24.7)$ & \\
\hline $62-68$ & $17(10.5)$ & \\
\hline \multicolumn{3}{|l|}{ Marital status } \\
\hline Married & $123(75.9)$ & (Married) \\
\hline Single & $39(24.1)$ & \\
\hline \multicolumn{3}{|l|}{ Household size } \\
\hline $1-2$ & $20(12.4)$ & \\
\hline $3-4$ & $39(24.1)$ & \\
\hline $5-6$ & $66(40.7)$ & 5.02 \\
\hline $7-8$ & $31(19.1)$ & \\
\hline $9-10$ & $6(3.7)$ & \\
\hline \multicolumn{3}{|l|}{ Educational status } \\
\hline Primary school (6) & $47(29.0)$ & \\
\hline Junior Secondary school (9) & $9(5.6)$ & \\
\hline Senior Secondary school (12) & $53(32.7)$ & $(\mathrm{SSS})$ \\
\hline $\mathrm{OND} / \mathrm{NCE} / \mathrm{HND}(14-15)$ & $36(22.2)$ & \\
\hline University degree $(16-17)$ & $17(10.5)$ & \\
\hline Fish farming experience(years) & & \\
\hline
\end{tabular}




\begin{tabular}{|l|c|c|}
\hline Parameter & Frequency & $\begin{array}{c}\text { Mean } \\
\text { (Mode) }\end{array}$ \\
\hline $1-2$ & $28(17.3)$ & 4.44 \\
\hline $3-4$ & $60(37.0)$ & \\
\hline $5-6$ & $47(29.0)$ & \\
\hline $7-8$ & $22(13.6)$ & \\
\hline $9-10$ & $5(3.1)$ & \\
\hline Pond size $\left.\mathbf{( m}^{2}\right)$ & & 83.43 \\
\hline $36-58$ & $27(16.7)$ & \\
\hline $59-81$ & $56(34.6)$ & \\
\hline $82-104$ & $51(31.4)$ & \\
\hline $105-127$ & $18(11.1)$ & \\
\hline $128-150$ & $10(6.2)$ & \\
\hline & & \\
\hline Access to credit & & \\
\hline Have access & $88(44.7)$ & (No access) \\
\hline No access & & \\
\hline
\end{tabular}

Source: Computed from survey data, 2015

Note: * Figures in parentheses are percentages

acceptance of new practices especially of information-intensive and managementintensive practices (Caswell et al., 2001). Furthermore, apart from being early innovators that provide examples that may be copied by illiterate farmers, educated farmers are better able to copy those who adopt innovation first, thereby enhancing wider diffusion of the new technology in the community (Samiee et. al., 2009).

Pond size is a very important factor in homestead fish production because it depends on the land area available for pond construction. Thus a number of potential investors in homestead fish farming are unable to do so because they do not have control over land that is around their home. Pond size ranged between $36 \mathrm{~m}^{2}$ and $150 \mathrm{~m}^{2}$, with an average of $83.43 \mathrm{~m}^{2}$. According to Doss and Morris (2001) farm size is the first and probably the most important determinant of participation in agricultural production. This is perhaps because farm size can affect, and in turn be affected by the other factors that influence the adoption of modern techniques of catfish production.

\section{Costs and Returns in Catfish Production}

The results of the costs and returns analysis in catfish production are shown in Table 3. Cost of labour and feeds are the most critical items of variable costs in catfish 
Table 3. Profitability in Homestead Catfish Production, Delta Central Agricultural, Zone.

\begin{tabular}{|l|r|}
\hline Parameter & Cost (A) \\
\hline Total Revenue & $\mathbf{2 4 1 , 0 9 4 . 1 5}$ \\
\hline Variable Cost items & \\
\hline Feeds & $55,489.09(31.42)^{*}$ \\
\hline Fingerlings & $11,893.59(6.73)$ \\
\hline Labour & $81,151.74(45.95)$ \\
\hline Water & $23,118.21(13.09)$ \\
\hline Fertiliser & $2,611.49(1.48)$ \\
\hline Other Expenses & $2,345.62(1.33)$ \\
\hline Total Variable Cost(TVC) & $\mathbf{1 7 6 , 6 0 9 . 7 5}$ \\
\hline & $16,309.03$ \\
\hline Fixed Cost items & $\mathbf{1 9 2 , 9 1 8 . 7 8}$ \\
\hline Depreciation costs of (ponds, water pump, nets. bore-hole, & $\mathbf{6 4 , 4 8 4 . 4 0}$ \\
\hline Total Costs(TC) & \\
\hline & \\
\hline Gross Margin(TR - TVC) & $\mathbf{4 8 , 1 7 5 . 3 7}$ \\
\hline & \\
\hline Net Margin(GM - FC) & $\mathbf{6 7 . 1 7}$ \\
\hline & \\
\hline Profitability/Efficiency ratios & 0.29 \\
\hline Net Margin/kg ( & \\
\hline Net Margin/m ${ }^{2}$ ( $)$ & \\
\hline Net Margin-TC-ratio (\%) & \\
\hline
\end{tabular}

Source: Computed from survey, 2015

Note: * Figures in parentheses are percentages of Total Variable Cost

${ }^{\dagger}$ US $\$ 1.00=\$ 170.00$

production. While labour cost constituted $45.95 \%$ fish feeds made up $31.42 \%$ of the variable costs of production. The net margin, which is total revenue less total cost of production was found to be $\$ 48,175.37$, implying that catfish production is profitable in the study area.

Also, the net margin $/ \mathrm{kg}$ was 67.17 . The results indicate that for every kilogramme of fish sold, the farmer earns a profit of 67.17 on the average. The combined effects of low yield and high cost of production, particularly of variable costs components such as labour and fish feeds are implicated for the rather low net margin per kilogramme. Although the net margin per kilogramme revealed the level of profitability, it is not a very critical measure because it does not take into consideration the total cost incurred by the farmer to earn that margin.

The net margin-to-total cost ratio is another measure of profitability that was used to further ascertain the level of profitability of catfish farming at the homestead level. 
The ratio was $0.29 \%$. The implication of the result is that investment in homestead catfish production earned as high as $29 \%$ return on capital invested. That is for every 100 kobo invested, the farmer earned a profit of 29 kobo. Therefore, homestead catfish production is profitable in the study area.

In order to test whether there is no significant difference in profit between homestead fish farms of different size categories, two categories of pond sizes were designated using the average pond size of $83.43 \mathrm{~m}^{2}$ as a cut-off point. Those farms with pond size $\leq 83 \mathrm{~m}^{2}$ were category ' $A$ ' while those $\geq 84 \mathrm{~m}^{2}$ were category ' $B$ '. The results of the test of differences in average net margin showed that there was statistically significant difference in net margin at the 1\% level of significance (Table 4). That is ponds in category ' $\mathrm{B}$ ' which were greater or equal to $84 \mathrm{~m}^{2}$ were significantly more profitable than those in category ' $A$ ' that were smaller in sizes. Therefore, significant difference in profit existed between homestead fish farms of the different size categories.

Table 4. Test of differences of mean profitability between ponds of two size categories

\begin{tabular}{|l|c|c|c|c|c|}
\hline Parameter & $\begin{array}{c}\text { Pond Size } \\
\text { Category A } \\
\left(\leq 83 \mathrm{~m}^{2}\right)\end{array}$ & $\begin{array}{c}\text { Pond Size } \\
\text { Category B } \\
\left(\geq 84 \mathrm{~m}^{2}\right)\end{array}$ & Mean Difference & t-statistic & p-value \\
\hline Net Margin & 17049.46 & 83396.81 & -66347.35 & -10.252 & $0.01^{*}$ \\
\hline
\end{tabular}

Source: Computed from survey, 2015

\section{Technical Efficiency in Catfish Production}

The results of the maximum likelihood estimates (MLE) of the stochastic production function used to determine the influence of specified inputs on catfish output as well as the effects of farmers' socio-economic characteristics on technical inefficiency are presented in Table 5. All the variables have positive and significant effects on catfish output. This implies that an increase in the use of these production inputs would raise output in homestead catfish production. The elasticity estimates which give an indication of how much fish output will vary as a result of a variation in a specified independent variable, while holding all others constant, revealed that pond size had the dominant influence with a value of 1.16; while the elasticity estimates for labour, feeds, and fingerlings were $0.21,0.24$, and 0.63 respectively. The results indicated that a $10 \%$ increase in pond size will lead to $11.6 \%$ rise in catfish output, while a concomitant change in labour, feeds, and fingerlings cause a $2.1 \%, 2.4 \%$ and a $6.3 \%$ increase in catfish output. The findings are in consonance with that of Ekunwe and Omokaro (2009) on the positive significant influence of labour on catfish production in Kaduna State. Onoja and Achike (2011) found stock size and feeds to exert positive and significant effects on catfish out in Rivers State; Omobepade, Adebayo and Amos (2014) reported positive and significant impact of labour, feeds and fingerlings on fish output in Ekiti State; Penda, Umeh and Unaji (2013) found labour and fingerlings to positively and significantly affect fish output in earthen pond system in Benue State, 
while Ogundari and Ojo (2009) found pond size, feeds and fingerlings as significant determinants of fish output in Oyo State, all in Nigeria.

Table 5. Maximum Likelihood Estimates of Parameters of Stochastic Frontier Production Function

\begin{tabular}{|l|c|c|c|c|}
\hline Variable & Parameter & Coefficient & $\begin{array}{c}\text { Standard } \\
\text { error }\end{array}$ & t-ratio \\
\hline Constant & $\beta_{0}$ & -8.26 & 0.85 & -9.77 \\
\hline Pond size & $\beta_{1}$ & 1.16 & 0.14 & $8.11^{* * *}$ \\
\hline Labour & $\beta_{2}$ & 0.21 & 0.065 & $3.23^{* * *}$ \\
\hline Feeds & $\beta_{3}$ & 0.24 & 0.07 & $3.44^{* * *}$ \\
\hline Fingerlings & $\beta_{4}$ & 0.63 & 0.083 & $7.58^{* * *}$ \\
\hline Inefficiency Parameters & & & & \\
\hline Constant & $\delta_{0}$ & -1.36 & 0.94 & -1.45 \\
\hline Age & $\delta_{1}$ & -0.035 & 0.017 & $-2.06^{* * *}$ \\
\hline Household size & $\delta_{2}$ & 0.39 & 0.14 & $2.85^{* * *}$ \\
\hline Formal education & $\delta_{3}$ & -0.09 & 0.032 & $-2.83^{* * *}$ \\
\hline Farming experience & $\delta_{4}$ & 0.07 & 0.046 & 1.52 \\
\hline Credit Access & $\delta_{5}$ & -0.82 & 0.39 & $-2.13^{* * *}$ \\
\hline Variance parameters & & & & \\
\hline Sigma squared & $\sigma^{2}$ & 0.49 & 0.13 & $3.87^{* * *}$ \\
\hline Gamma & $\gamma$ & 0.70 & 0.10 & $6.76^{* * * *}$ \\
\hline Log likelihood function & $\mathrm{L}$ & -87.33 & & \\
\hline
\end{tabular}

Source: Computed from survey, 2015

Note: $* *$ Significant at $5 \%$ level of significance; $* * *$ significant at the $1 \%$ level of significance

The return to scale (RTS) of the farm firms (Table 6), which is the sum of the elasticities of production, was computed to be 2.24. It revealed that catfish farms exhibited increasing return to scale. The RTS implies that if all the inputs are jointly increased by $1 \%$, output will increase by $2.24 \%$. This result is similar to those of Ogundari and Ojo (2009) and Onoja and Achike (2011) who reported the existence of increasing returns to scale in catfish production in Oyo and River States of Nigeria, respectively.

Table 6. Elasticity of production and Return to Scale

\begin{tabular}{|l|c|}
\hline Variable $\left(\boldsymbol{x}_{\boldsymbol{i}}\right)$ & Elasticities \\
\hline Pond size & 1.16 \\
\hline Labour & 0.21 \\
\hline Feeds & 0.24 \\
\hline Fingerlings & 0.63 \\
\hline RTS & 2.24 \\
\hline
\end{tabular}

Source: Computed from survey, 2015 


\section{Determinants of Technical Inefficiency}

The results of the technical efficiency of catfish production in the study area are also shown in lower segment of Table 5. The sigma squared) is an indication of the goodness of fit of the model applied as well as the correctness of the specified distributional assumption of the composite error term. It was statistically significant at $1 \%$ level. The gamma estimate $(=0.70)$ indicated that $70 \%$ variation in output in catfish production in the Delta Central agricultural zone, of Delta State is due to technical inefficiency, rather than random variability. Therefore, the hypothesis which stated that there are no inefficiency effects in the stochastic frontier model for catfish production is rejected (Table 7). The presence of inefficiency in catfish production in the area is corroborated by the range of estimated technical efficiency (TE) in the study which ranged from 0.28 -0.96 with a mean of 0.87 (Table 8). The mean TE implies that $13 \%$ of output of catfish in an average farm is lost due to inefficiency in the production process. The frequency distribution of the technical efficiency of homestead fish farms shows that about $94 \%$ of the farms were at least $76 \%$ technically efficient. Ekunwe and Omokaro (2009) and Ogundari and Ojo (2009) reported comparable findings on average $\mathrm{TE}$ in catfish farms in other parts of Nigeria.

Table 7. Results of Test of Hypothesis of Technical Inefficiency in Catfish Production

\begin{tabular}{|l|c|c|c|}
\hline Null hypothesis & $\begin{array}{c}\text { Likelihood ratio } \\
\text { statistic }\end{array}$ & Critical value & Decision \\
\hline $\begin{array}{l}\text { No inefficiency effects in the model; } \gamma=\delta_{1}= \\
\hat{\beta}_{2}=\delta_{3}=\delta_{4}=\delta_{5}=0\end{array}$ & 13.62 & $13.40^{*}$ & Reject \\
\hline
\end{tabular}

Source: Computed from survey, 2015

Note: * Significant at $5 \%$ level of significance

The results of the determinants of inefficiency are also shown in Table 5. The results indicate that household size have positive and significant effects on inefficiency, while the influence of age, formal education and access to credit was negative. The implication of these results are that an increase in household size and farming experience led to increase in technical inefficiency but decreased TE; while an increase age, formal education and access to credit decreased technical inefficiency, they lead to an increase in TE. Farming experience, though have no significant effects on technical inefficiency its positive sign is contrary to a priori expectation. Age of the farmer had a positive and significant impact on TE. Older people are keener to participate in new technologies because they have more personal capital from long accumulation (Tenge et al.; 2004; Nkamleu and Manyong, 2005; Girei, Dire, Iliya and Salihu, 2013). Years of formal education are another variable that had a positive and significant influence on TE. Operators who spent more years in school acquiring formal education are more likely to carry on production operations more efficiently in catfish farming than their less educated counterparts. This result is in consonance with 
Table 8. Distribution of Estimates of Technical Efficiency in Homestead Catfish Production

\begin{tabular}{|l|c|}
\hline Efficiency class & Frequency \\
\hline $0.28-0.39$ & $1(0.62)^{*}$ \\
\hline $0.40-0.51$ & $2(1.24)$ \\
\hline $0.52-0.63$ & $1(0.62)$ \\
\hline $0.64-0.75$ & $6(3.70)$ \\
\hline $0.76-0.87$ & $46(28.39)$ \\
\hline $0.88-0.99$ & $106(65.43)$ \\
\hline Minimum & 0.28 \\
\hline Maximum & 0.96 \\
\hline Mean & 0.87 \\
\hline
\end{tabular}

Source: Computed from survey, 2015

Note: * Figures in parentheses are percentages

those of Ogundari and Ojo (2009) and Girei, et al. (2013). Access to credit also exerted a significant influence on TE in homestead catfish production. The result indicated that individuals who have access to credit are more technically efficient in production because of the ready availability of credit to procure resources needed to carry out farm operations as soon as the need arises. Therefore, the hypothesis that stated that there was no technical inefficiency in catfish production is rejected.

In order to test whether there is no significant difference in technical efficiency between homestead catfish farms of different size categories, two categories of pond sizes were designated using the average pond size of $83.43 \mathrm{~m}^{2}$ as a cut-off point. Those farms with pond size $\leq 83 \mathrm{~m}^{2}$ were category ' $A$ ' while those $\geq 84 \mathrm{~m}^{2}$ were category ' $B$ '. The results of the test of differences in mean $\mathrm{TE}$ showed that there was no significant difference in TE between farms in the two size categories (Table 9).

Table 9. Test of differences of mean technical efficiency between farms of two size categories

\begin{tabular}{|l|c|c|c|c|c|}
\hline \multicolumn{1}{|c|}{ Parameter } & $\begin{array}{c}\text { Pond Size } \\
\text { Category A } \\
\left(\leq 83 \mathrm{~m}^{2}\right)\end{array}$ & $\begin{array}{c}\text { Pond Size } \\
\text { Category B } \\
\left(\geq 83 \mathrm{~m}^{2}\right)\end{array}$ & $\begin{array}{c}\text { Mean } \\
\text { Difference }\end{array}$ & t-statistic & Significance \\
\hline $\begin{array}{l}\text { Technical } \\
\text { Efficiency }\end{array}$ & 0.8772 & 0.8563 & 0.02096 & 1.497 & 0.136 \\
\hline
\end{tabular}

Source: Computed from survey, 2015

\section{Conclusions}

This study examined the profitability and resource use efficiency in homestead catfish production in the central agricultural zone of Delta State, Nigeria. The study adopted budgetary analysis and stochastic frontier production (SFP) analysis to achieve the stated objectives. The results showed that catfish production was profitable with a net 
margin/ $\mathrm{kg}$ of 67.17 ; net margin $/ \mathrm{m}^{2}$ of 490.31 and a net margin-to-total cost ratio of $29 \%$. The results of the SFP analysis indicated that all the independent variables; pond size, feeds, fingerlings and labour exerted positive and statistically significant effects on fish output in homestead catfish production. The technical efficiency (TE) of homestead catfish farms ranged from $28 \%$ to $96 \%$ with an average of $87 \%$. Further analysis indicated that household size had a positive and significant influence on inefficiency, while age of the farmer, level of formal education and access to credit had negative and significant effects on inefficiency. Thus these farmer specific characteristics have the capacity to increase technical efficiency in fish production at the homestead level. The returns to scale value of 2.26 implied increasing returns to scale and that homestead fish production is within stage I of the total production curve. This is an indication that catfish production holds great potentials for increased productivity in the area. Although catfish production was found to be profitable, the factors that were implicated for the inefficiency in the production process should be improved upon in order to attain optimality in production. We therefore recommend that empowerment programmes of government and other development institutions should be targeted to training catfish farmers and prospective farmers to acquire requisite skills in pond fish management. Furthermore, credit schemes should be implemented to make short-term credit readily available to homestead fish producers to finance their operations. Homestead catfish producers should be encouraged to form cooperative societies in order to pull their resource together to help boost output and enhance household food security in both the urban and rural areas of Delta State, Nigeria.

\section{Acknowledgements}

The authors wish to thank the Tertiary Education Trust Fund (TetFund) and the Research and Publications Committee of the Delta State University, Abraka, Nigeria, for the grant for funding the research work.

\section{Literature}

1. Adeogun, O.A., Ajana, A.M., Ayinla, O.A., Yarhere, M.T., Adeogun, M.O. (2008): Application of Logit Model in Adoption Decision: a Study of Hybrid Clarias in Lagos State, Nigeria. American-Eurasian Journal of Agriculture and Environmental Science, Vol. 4, No. 4, pp. $468-472$.

2. Aigner, D.J., Lovell, C.A.K., Schmidt, P. (1977): Formulation and estimation of stochastic frontier production models. Journal of Econometrics, Vol. 6, pp. 21-32.

3. Amsalu, A., de Graaff, J. (2007): Determinants of adoption and continued use of stone terraces for soil and water conservation in an Ethiopian highland watershed. Ecological Economics, Vol. 61, No. 2\&3, pp. 294-302. 
4. Caswell, M., K. Fuglie., C. Ingram., S. Jans and Kascak, C. (2001): Adoption of Agricultural production practices: Lessons learned from the US. Department of Agriculture area studies project. Washington DC. US Department of Agriculture. Resource Economics Division, Economic Research service, Agriculture Economic Report No.792.

5. Chukwuji, C. O., Inoni, O. E., Ike, P. C. (2007): Determinants of Technical Efficiency in Gari Processing in Delta State Nigeria. Journal of Central European Agriculture, Vol. 8, No. 3, pp. 327 - 336.

6. Coelli, T.J. (1996): FRONTIER version 4.1c: A Computer programme for Stochastic Frontier production and Cost Function Estimation. Working paper 96/07, Centre for Efficiency and Productivity Analysis Dept. of Econometrics, University of New England, Armidale, Australia.

7. Coelli, T.J., Rao, D.S.P., O’Donnell, C.J., Battese, G.E. (2005): An Introduction to efficiency and Productivity Analysis. 2nd Edition. Springer, New York, U.S.A.

8. Doss, C.R., Morris, M. L. (2001): How Does Gender Affect the Adoption of Agricultural Innovation? The Case of Improved Maize Technologies in Ghana. Journal of Agricultural Economics, Vol. 25, pp. 27 - 39.

9. Ekunwe, P.A., Emokaro, C.O (2009): Technical Efficiency of Catfish Farmers in Kaduna, Nigeria, Journal of Applied Sciences Research, Vol. 5, No. 7, pp. 802-805.

10. F.A.O. (2006). Yearbook of Fisheries and Aquaculture Statistics. Food and Agriculture Organisation of the United Nations, Rome, Italy.

11. F.A.O. (2008). Yearbook of Fisheries and Aquaculture Statistics. Food and Agriculture Organisation of the United Nations, Rome, Italy.

12. F.A.O. (2009). Yearbook of Fisheries and Aquaculture Statistics. Food and Agriculture Organisation of the United Nations, Rome, Italy.

13. F.A.O. (2014). Yearbook of Fisheries and Aquaculture Statistics 2012). Food and Agriculture Organisation of the United Nations, Rome, Italy.

14. F.A.O. (2016). Yearbook of Fisheries and Aquaculture Statistics 2014). Food and Agriculture Organisation of the United Nations, Rome, Italy

15. F.A.O. (2016). The State of World Fisheries and Aquaculture 2016. Food and Agriculture Organisation of the United Nations, Rome, Italy.

16. F.A.O. (2017): FishstatJ_3.03.0_win64 Software. Food and Agriculture Organisation of the United Nations, Rome, Italy.

17. Girei, A.A., Dire, B., Iliya, M.M., Salihu, M. (2013): Stochastic Frontier Production Function on the Resource Use Efficiency of Fadama Ii Crop Farmers in Adamawa State, Nigeria. European Journal of Agricultural and Forestry Research, Vol. 1, No. 2, pp. 1-15.

18. Greene, W. H. (2008): Econometric Analysis (6th edition), Pearson-Prentice Hall, New Jersey, U.S.A.. 
19. Inoni, O. E. (2007): Allocative Efficiency in Pond Fish Production in Delta State, Nigeria: A Production Function Approach. Agricultura Tropica Et Subtropica, Vol. 40, No. 4, pp. $127-134$.

20. Nkamleu, G. B., Manyong, V. M. (2005 ): Factors Affecting the Adoption of Agroforestry Practices by Farmers in Cameroon. Small-scale Forest Economics, Management and Policy, Vol. 4, No. 2, pp.135 - 148.

21. Ogundari, K., Ojo, S.O. (2009): An Examination of Income Generation Potential of Aquaculture Farms in Alleviating Household Poverty: Estimation and Policy Implications from Nigeria. Turkish Journal of Fisheries and Aquatic Sciences, Vol. 9, pp. 39-45.

22. Olagunju, F. I., Adesiyan, I. O., Ezekiel, A. A. (2007): Economic Viability of CatFish Production in Oyo State, Nigeria. Journal of Human Ecology, Vol. 21, No. 2, pp. $12-124$.

23. Olawumi, A.T., Dipeolu, A. O., Bamiro, O. M. (2010): Economic Analysis of Homestead Fish Production in Ogun State Nigeria. Journal of Human Ecology, Vol. 31, No. 1, pp. 13-17.

24. Omobepade, B.P., Adebayo, O.T., Amos, T.T. (2014): Technical Efficiency of Aquaculturists in Ekiti State, Nigeria Journal of Aquaculture Research and Development, Vol. 5, No. 5, pp. 2155 - 9546.

25. Onoja, A. O., Achike, A.I. (2011): Resource Productivity in Small-Scale Catfish (Clarias Gariepinus) Farming in Rivers State, Nigeria: A Translog Model Approach. Journal of Agriculture and Social Research, Vol. 11, No. 2, pp. 139 - 146.

26. Penda, S.T., Umeh, J. C., Unaji, G. P. (2013): Resource Use Efficiency among Fish Farmers Using Earthen Pond System in Benue State, Nigeria. International Journal of Research in Social Sciences, Vol. 3, No. 1, pp. $62-68$.

27. Samiee, A., Rezvanfa, A., Faham, E. (2009): Factors Influencing the Adoption of Integrated Pest Management (IPM) by Wheat Growers in Varamin County, Iran. African Journal of Agricultural Research, Vol. 4, No. 5, pp. 491-497.

28. Tenge, A. J., Graaff, J. D., Hella, J. P. (2004): Social and Economic Factors Affecting the Adoption of Soil and Water Conservation in West Usambara highlands, Tanzania. Land Degradation and Development, Vol. 15, No. 2, pp. $99-114$.

29. Ugwumba, C.O.A., Chukwuji, C.O. (2010): The Economics of Catfish Production in Anambra State, Nigeria: A Profit Function Approach. Journal of Agriculture and Social Sciences, Vol. 6, No. 4, pp. 105-109

30. Ugwumba, C.O.A. (2005): The Economics of Homestead Concrete Fish Pond in Anambra State, Nigeria. African Journal of Fisheries and Aquaculture, Vol. 4, pp. 28-32. 
ECONOMICS OF

AGRICULTURE

\section{CONTENT}

1. Adriana Radosavac, Desimir Knežević

ECONOMIC IMPORTANCE OF USE

OF PESTICIDES IN WHEAT PRODUCTION . . . . . . . . . . . 1323

2. Berhe Gebregewergs, Muuz Hadush

DOES CLIMATE CHANGE AFFECT PRICE OF VEGETABLES:

EVIDENCE FROM TIGRAI, NORTHERN MOST ETHIOPIA. . . . .1335

3. Grujica Vico, Aleksandra Govedarica-Lučić, Zoran Rajić, Radomir Bodiroga, Ivan Mičić, Silvija Zec Sambol, Marija Mičić

MULTI ATTRIBUTE ASSESSMENT APPROACH

IN VEGETABLE PRODUCTION . . . . . . . . . . . . . . 1355

4. Igor Trandafilović, Vesna Conić, Aleksandra Blagojević

IMPACT OF DEMOGRAPHIC FACTORS ON

ENVIRONMENTALLY CONSCIOUS PURCHASE BEHAVIOUR. . .1365

5. Imre Milán Harcsa

STUDY ON THE POTENTIAL OF SUBCONTRACT

PALINKA DISTILLATION . . . . . . . . . . . . . . 1379

6. Jelena Andrašić, Vera Mirović, Nada Milenković, Branimir Kalaš, Miloš Pjanić

IMPACT OF TAKEOVER PROCESS ON EMPLOYEES -

EVIDENCE FROM FOOD, RETAIL AND FINANCIAL SECTOR . . .1393

7. Jelena Birovljev, Danilo Đokić, Bojan Matkovski, Žana Kleut

ECONOMIC PERFORMANCES OF AGRICULTURE

OF CEFTA AND FORMER CEFTA COUNTRIES . . . . . . . . . . 1413

8. Jelena Marković, Svetlana Stevović

SUSTAINABILITY OF CHEMICAL SOIL QUALITY

IN SOUTHERN MORAVA RIVER VALLEY

IN CORELLATION WITH THE FLOODING $\ldots \ldots \ldots \ldots \ldots$ 
9. Mile Peševski, Zoran Milovančević

THE CHANGES IN THE USAGE OF AGRICULTURAL LAND

IN EASTERN REGION OF REPUBLIC OF MACEDONIA

BETWEEN $1991-2030 \ldots \ldots$. . . . . . . . . . . . . . . . . . . . . . .

10. Odjuvwuederhie Emmanuel Inoni, 'Oraye Dicta Ogisi, Felix Odemero Achoja

PROFITABILITY AND TECHNICAL EFFICIENCY IN HOMESTEAD

CATFISH PRODUCTION IN DELTA STATE, NIGERIA . . . . . . . 1449

11. Olja Munitlak - Ivanović, Jovan Zubović, Petar Mitić

RELATIONSHIP BETWEEN SUSTAINABLE DEVELOPMENT AND

GREEN ECONOMY - EMPHASIS ON GREEN FINANCE

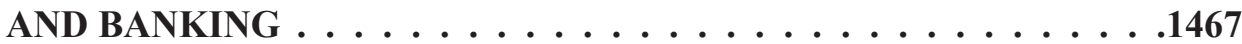

12. Petar Munćan, Dragica Božić

FARM SIZE AS A FACTOR OF EMLOYMENT AND INCOME

OF MEMBERS OF FAMILY FARMS . . . . . . . . . . . . . 1483

13. Rade Popović, Mira Kovljenić

EFFICIENCY OF WHEAT PRODUCTION ON FARMS

IN THE REPUBLIC OF SERBIA . . . . . . . . . . . . . . . . . . . . . . . . .

14. Radovan Damnjanović, Snežana Krstić, Milena Knežević, Svetislav Stanković,

Dejan Jeremić

THE DISCRIMINANT ANALYSIS APPLIED TO THE

DIFFERENTIATION OF SOIL TYPES . . . . . . . . . . . . 1513

15. Slavica Otović, Dunja Demirović, Kristina Košić, Aleksandra Vujko

FOSTERING ENTERPRENUERSHIP AT HIGH SCHOOLS:

A CASE OF RURAL AREAS IN VOJVODINA (SERBIA) . . . . . . .1523

16. Vladimir Ilić, Ivan Bauer, Anastazija Tanja Đelić, Aleksandar Nešković

INSTITUTIONAL SUPPORT FOR STRENGTHENING

ENTREPRENEURSHIP IN AGRICULTURAL PRODUCTION

OF THE REPUBLIC OF SERBIA . . . . . . . . . . . . . . . . . . . . . . . .

17. Boro Krstić, Zorica Vasiljević, Miroslav Nedeljković

INSURANCE CONTRACT AS THE BASIS FOR THE SAFETY OF

AGRICULTURAL PRODUCERS IN THE REPUBLIC OF SRPSKA • . 1555

18. Dejan Sekulić, Aleksandar Petrović, Vladimir Dimitrijević

WHO ARE WINE TOURISTS? AN EMPIRICAL INVESTIGATION

OF SEGMENTS IN SERBIAN WINE TOURISM . . . . . . . . . . . . . 
19. Milan Beslać, Ćorić Goran

FINANCIAL AND PRODUCTION ASPECTS OF GENETICALLY MODIFIED ORGANISMS $\ldots \ldots \ldots \ldots \ldots \ldots \ldots \ldots \ldots$

20. Mlađan Maksimović, Darjan Karabašević, Miodrag Brzaković, Pavle Brzaković THE EFFECTS RESULTING FROM THE APPLICATION OF THE CONCEPT OF THE SUSTAINABLE DEVELOPMENT OF RURAL TOURISM ON STARA PLANINA . . . . . . . . . . . . . . . .1595

21. Vesna Popović, Predrag Vuković, Milivoje Ćosić FOOD SAFETY AND QUALITY POLICY IN THE REPUBLIC OF SERBIA . . . . . . . . . . . . . . . . 1607

22. Radovan Pejanović, Danica Glavaš-Trbić, Mirela Tomaš-Simin PROBLEMS OF AGRICULTURAL AND RURAL DEVELOPMENT IN SERBIA AND NECESSITY OF NEW AGRICULTURAL POLICY . . . .1619

23. Saša Marković, Slavoljub Vujović, Aleksandar Damnjanović MARKETING AND HIGHER EDUCATION CONDITION IN SERBIA . . . . . . . . . . . . . . . . 1635

24. Semir Vehapi, Marina Milanović THE EFFECT OF MARKET ORIENTATION ON BUSINESS PERFORMANCE OF SERBIAN ORGANIC PRODUCERS . . . . . 1651

25. Suad Bećirović, Šemsudin Plojović, Enis Ujkanović, Senadin Plojović CHALLENGES AT STARTING AN AGRIBUSINESS IN THE HILLY MOUNTAINOUS REGIONS OF SOUTHWEST SERBIA . . . . . . . .1669

26. Vladimir Zakić, Vlado Kovačević, Jelena Damnjanović SIGNIFICANCE OF FINACIAL LITERACY FOR THE AGRICULTURAL HOLDINGS IN SERBIA . . . . . . . . . . 1687

27. Željko Bjelajac, Marijana Dukić Mijatović, Željko Vojinović PROTECTION OF LAND IN THE REPUBLIC OF SERBIA AND ECOLOGICAL SECURITY WITH REGARD TO STRATEGIC AND LEGAL FRAMEWORKS . . . . . . . . . .1703 